\title{
ASSESSMENT OF WATER QUALITY IN DRAINAGE CANALS OF ÇARŞAMBA PLAIN, TURKEY, THROUGH WATER QUALITY INDEXES AND GRAPHICAL METHODS
}

\author{
GÜNGÖR A. ${ }^{1}$ \\ ARSLAN H. ${ }^{2, *}$
}

\author{
${ }^{1}$ Department of Biosystems Engineering \\ Ahi Evran University, Kirşehir, Turkey \\ ${ }^{2}$ Ondokuz Mayis University, Faculty of Agriculture \\ Department of Agricultural Structures and Irrigation
}

55139 Samsun-Turkey

Received: $11 / 09 / 2015$

Accepted: 09/12/2015

Available online: 15/01/2016

\begin{abstract}
In this study, the seasonal variation on drainage water quality of Çarşamba Plain, Turkey has been evaluated from July 2012 to January 2013 and determined the suitability of water for irrigation purpose. Water samples collected from 21 drainage canals during July and January were analysed for 12 water quality parameters including physico-chemical analyses. Piper diagram and United States Salinity Laboratory (USSL) diagram were prepared to investigate water quality. Sodium Adsorption Ratio (SAR), Percent Sodium (Na\%), Residual Sodium Carbonate (RSC), Kelly Index (KI), Magnesium Ratio (MR), Langelier Saturation Index (LSI), Permeability Index (PI) and Potential Salinity (PS) were also used to assess suitability of waters for irrigation.

In July 2012, EC values varied between 0.45-4.23 dS $\mathrm{m}^{-1}$. Waters of 7 drainage canals were found to be unsuitable for irrigation with regard to $\mathrm{KI}, 3$ canals with regard to RSC and 13 canals with regard to MR. According to USSL diagram, $24 \%$ of drainage waters were classified in $\mathrm{C}_{2} \mathrm{~S}_{1}, 62 \%$ in $\mathrm{C}_{3} \mathrm{~S}_{1}, 4 \%$ in $\mathrm{C}_{4} \mathrm{~S}_{2}$ and $10 \%$ in $\mathrm{C}_{4} \mathrm{~S}_{4}$ class. In January 2013, EC values varied between 0.16-1.44 dS m $\mathrm{m}^{-1}$. Waters of one canal was found to be unsuitable for irrigation with regard to KI and 8 canals with regard to MR values.

The result obtained from paired sample $t$-test revealed that the drainage canal water quality varies significantly between July 2012 and January 2013 except for $\mathrm{Ca}, \mathrm{Mg}$ and $\mathrm{SO}_{4}$. According to analysed parameters, some of the drainage canals were considered unsuitable for irrigation in July 2012. The water properties of all canals were observed as unsuitable to be used for drip irrigation in accordance to the LSI index. Classification of drainage water by USSL diagrams indicates a low sodium and high salinity hazard.
\end{abstract}

Keywords: Salinity, Water quality, Piper diagram, Kelly index, Nitrate

\section{Introduction}

Global warming and resultant droughts have created water deficits in several parts of the world. Efficient water use is a unique means of struggle with water related problems. Drainage waters have been used for many years as an efficient water use practice throughout the world.

Chemical composition of drainage water vary based on several factors such as drainage system, agricultural practices, soil structure, soil infiltration rate, initial soil salinity, irrigation methods and climate. There are several studies carried out to assess the suitability of surface waters, ground waters or drainage waters for irrigation. Chemical composition of surface and ground waters is influenced by various 
factors like precipitation, climate, topography and characteristics of parent rocks. Such factors also significantly affect spatial and temporal variations in water classes.

There are various water quality assessment methods developed by different researchers and almost all of them use chemical characteristics of the waters. Graphical methods and different indexes are among the significant water quality assessment methods. Graphical methods are commonly employed to investigate water quality parameters (Kontis and Gaganis, 2012, Singh et al., 2013; Vetrimurugan et al., 2015; Yidana et al., 2012; Zrelli et al., 2012).

Various classifications have been made to assess the suitability of waters for irrigation. Electrical conductivity (EC) and sodium adsorption ratio (SAR) are the foremost values used in such assessments. Beside them, residual sodium carbonate (RSC), Kelly index, permeability index, magnesium ratio, potential salinity, Langelier Saturation Index are also commonly used in water quality assessments for irrigation. Several researchers used different index values to assess the suitability of surface and ground waters for irrigation (Arumugam and Elangovan, 2009; Dhembare, 2012; Ishaku et al., 2011; Nag et al., 2013; Rama et al., 2013; Sadashivaiah et al., 2008; Thivya et al., 2013; Wanda et al., 2013).

Alexakis et al. (2012) took water samples from drainage canals before and after irrigations in Greece and assessed the water quality of these canals. Researchers calculated SAR, RSC and \%Na values of the water samples and prepared piper diagram to present the chemistry of water samples and define water type. The water type of drainage canal was identified as $\mathrm{Na}-\mathrm{Cl}-\mathrm{SO}_{4}$ and found to be unsuitable for irrigations. Set et al. (2015) assessed the suitability of surface waters for irrigation in India. Piper diagram and USSL diagram were prepared; SAR, RSC and Na \% values were determined to assess the suitability of river water for irrigation purposes.

In this study, water samples were taken from 21 drainage canals in July 2012 and January 2013 to determine seasonal variations in water quality and to assess the suitability of canal waters for irrigation through graphical methods and different index values.

\section{Materials and methods}

\subsection{Study area}

The study area covers Çarşamba Plain which is one of the largest plains of Turkey. It is located in the Middle of Black Sea Region $\left(41^{\circ} 11^{\prime}-41^{\circ} 23^{\prime} E, 36^{\circ} 30^{\prime}-37^{\circ} 00^{\prime}\right.$ ) (Figure 1). The elevations range from 0.0 to $18.0 \mathrm{~m}$ above the sea level with slope gradients approximately $0.1 \%$. The climate is humid, with an average annual precipitation of about $1020 \mathrm{~mm}$ and an average annual temperature of $14.4^{\circ} \mathrm{C}$. The summers are warmer than winters (the average temperature in July is 23.30 and in January is $6.40{ }^{\circ} \mathrm{C}$ ). The total of 797 $\mathrm{mm}$ of precipitation was received from July 2012 to January 2013. The total study area is approximately 50000 ha. The soils of study area formed from alluvium on different elevations. Majority of the soil are deeper than $1.5 \mathrm{~m}$. The soils are fine-textured with moderate hydraulic conductivity. Crop patterns in the study area vary considerably. Hazelnut, wheat, corn, rice are extensively cultivated and there is not any irrigation canals in the study area. Therefore, groundwater or drainage canal waters are used as irrigation water.

\subsection{Sampling and analyses}

Water samples were taken from 21 drainage canals in July 2012 and January 2013 (Figure 1). A total of 42 water samples were collected from drainage canals. Global coordinates of each sampling location were recorded with the help of global positioning system (GPS). The electrical conductivity (EC) and pH were measured in situ. Sodium ( $\mathrm{Na})$, calcium $(\mathrm{Ca})$, magnesium $(\mathrm{Mg})$, potassium $(\mathrm{K})$, carbonate $\left(\mathrm{CO}_{3}\right)$, bicarbonate $\left(\mathrm{HCO}_{3}\right)$, chlorine $(\mathrm{Cl})$, sulphate $\left(\mathrm{SO}_{4}\right)$, nitrate $\left(\mathrm{NO}_{3}\right)$ and boron $(\mathrm{B})$ concentrations of drainage waters were determined. All samples were filtered through $0.45-\mu \mathrm{m}$ filter and sealed in polyethylene botteles. Calcium ( $\mathrm{Ca}$ ) and magnesium $(\mathrm{Mg})$ were determined titrimetrically using standard EDTA. Chloride $(\mathrm{Cl})$ by standard $\mathrm{AgNO}_{3}$ titration and $\mathrm{CO}_{3}$ and $\mathrm{HCO}_{3}$ levels were measured by titration. $\mathrm{Na}$ and $\mathrm{K}$ were determined by flame photometry. Sulphate $\left(\mathrm{SO}_{4}\right)$ was determined by spectrophotometer. Nitrates 
were measured by a colorimetric method. Boron was determined by calorimeter indigo-carmine method. The measurements was performed in triplicate.

Paired sample $t$ test was used to show seasonal changes using $p$ values, where $p<0.05$ was considered to be significant

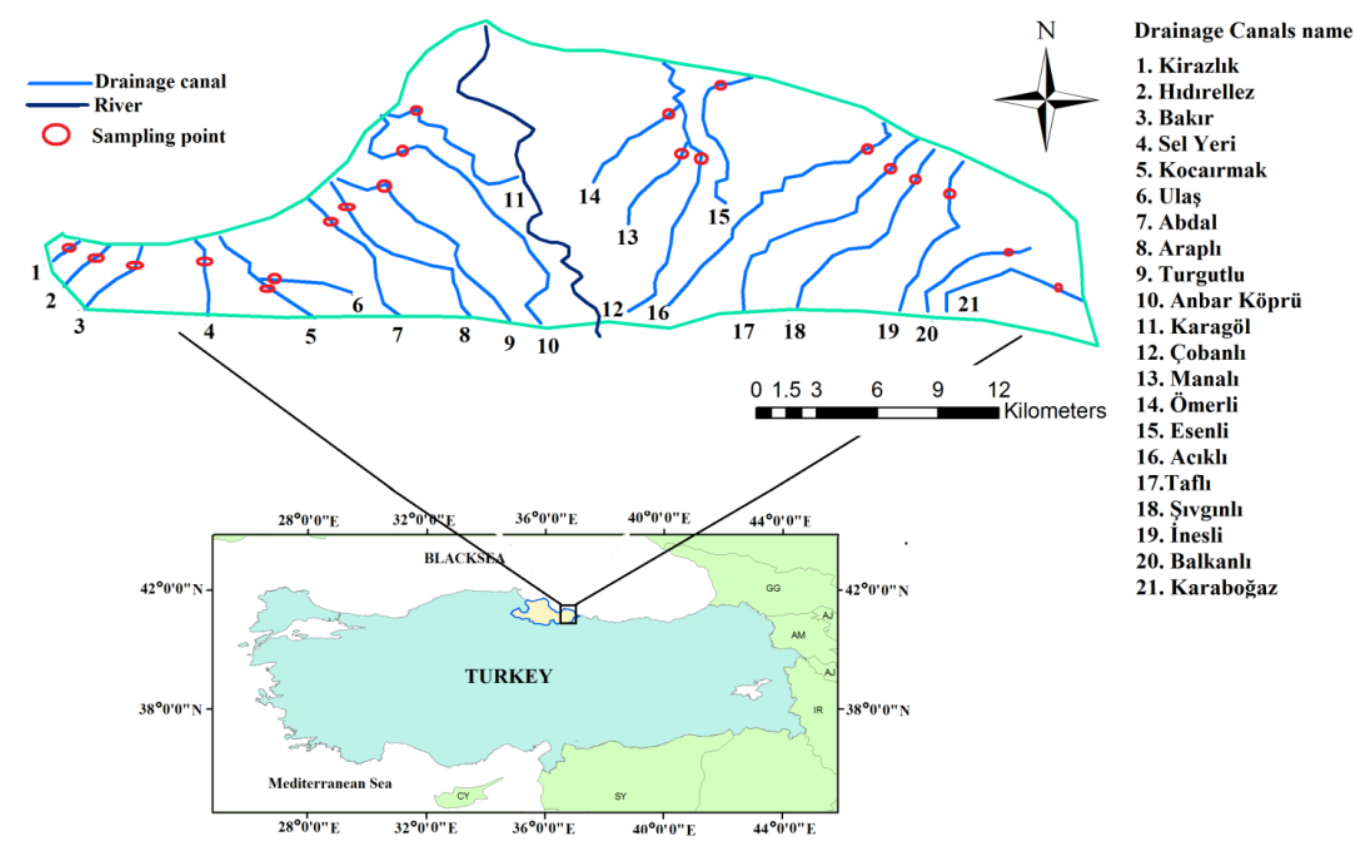

Figure 1. Study area and sampling points

\subsection{Analytical methods}

To assess the suitability of drainage waters for irrigation, $\mathrm{EC}$ and $\mathrm{pH}$ values were investigated and $\mathrm{SAR}, \%$ $\mathrm{Na}, \mathrm{RSC}, \mathrm{KI}, \mathrm{MR}, \mathrm{LSI}, \mathrm{PI}$ and PS values were calculated by using major anion and cation values. Besides, piper diagram and USSL salinity diagram were prepared to investigate water types.

Electrical conductivity is a useful parameter to measure salinity hazard to crops. High salt content in irrigation water causes an increase in osmotic pressure of soil solution. The classification of water samples based on EC values is shown in Table 1.

Table 1. Classification of water based on EC $\left(\mathrm{dS} \mathrm{m}^{-1}\right)$

\begin{tabular}{cc}
\hline Water salinity & EC \\
\hline Low & $<0.25$ \\
\hline Medium & $0.25-0.75$ \\
\hline High & $0.75-2.25$ \\
\hline Very high & $>2.25$ \\
\hline
\end{tabular}

Waters with low salinity can be used for almost all plants and soil types. However, the waters of medium salinity can be used for moderately salt-tolerant plants. High salinity water can be used for irrigation purposes with some management practices and very high salinity water normally can not be used for irrigation purposes except for extreme salt-tolerant plants.

Another important chemical parameter for judging the degree of suitability of water for irrigation is sodium content, which is expressed as SAR (Arslan and Demir, 2013). SAR is calculated using the following equation (1) (Richard, 1954). Ion concentrations in all equations are in meq $\mathrm{l}^{-1}$. The classification of water samples based on SAR values is shown in Table 2 . 
$\mathrm{SAR}=\frac{\mathrm{Na}}{\sqrt{\frac{\mathrm{Ca}+\mathrm{Mg}}{2}}}$

Table 2. Classification of groundwater based on SAR values

\begin{tabular}{cc}
\hline Water quality & SAR \\
\hline Excellent & $<10$ \\
\hline Good & $10-18$ \\
\hline Doubtful & $18-26$ \\
\hline Unsuitable & $>26$ \\
\hline
\end{tabular}

The sodium in irrigation waters is usually denoted as percent of sodium. $\% \mathrm{Na}$ is also used to assess the suitability of waters for irrigation. The percent sodium (\% $\mathrm{Na}$ ) values were obtained by using Equation (2). The classification of water samples based on \% Na values is shown in Table 3 (Wilcox ,1955)

$$
\% \mathrm{Na}=\frac{\left(\mathrm{Na}^{+}\right) * 100}{\left(\mathrm{Na}^{+}+\mathrm{Ca}^{2+}+\mathrm{Mg}^{2+}+\mathrm{K}^{+}\right)}
$$

Table 3. Classification of groundwater based on \%Na values

\begin{tabular}{cc}
\hline Water quality & Sodium (\%) \\
\hline Excellent & $<20$ \\
\hline Good & $20-40$ \\
\hline Permissible & $40-60$ \\
\hline Doubtful & $60-80$ \\
\hline Unsuitable & $>80$ \\
\hline
\end{tabular}

Residual Sodium Carbonate (RSC) is the excess sum of carbonate and bicarbonate in drainage canal water over the sum of calcium and magnesium. RSC values were calculated by using Equation (3). The classification of drainage water based on RSC is shown in Table 4 (Eaton, 1950).

$$
\mathrm{RSC}=\left(\mathrm{HCO}_{3}{ }^{-}+\mathrm{CO}_{3}{ }^{2-}\right)-\left(\mathrm{Ca}^{2+} \mathrm{Mg}^{2+}\right)
$$

Table 4. Classification of groundwater based on RSC values

\begin{tabular}{cc}
\hline Water quality & RSC \\
\hline Good & $<1.25$ \\
Medium & $1.25-2.50$ \\
Unsuitable & $>2.50$ \\
\hline
\end{tabular}

According to Kelly index, the waters with an index value over 1 are assessed as unsuitable for irrigation (Kelly, 1940). Kelly index was calculated by using Equation (4).

$$
\mathrm{KI}=\left[\frac{\mathrm{Na}^{+}}{\mathrm{Ca}^{2+}+\mathrm{Mg}^{2+}}\right]
$$

Magnesium ratio (MR) should be lower than $50 \%$ in irrigation waters since the values above $50 \%$ may result in sodicity problem in soils. MR is calculated by the following formula (Szabolcs and Darab, 1964)

$$
\text { M.R. }=\left[\frac{\mathrm{Mg}^{2+}}{\mathrm{Ca}^{2+}+\mathrm{Mg}^{2+}}\right]
$$

Potential salinity (PS) estimates the hazard of high salt concentration due to $\mathrm{Cl}$ and $\mathrm{SO}_{4}$ which can increase the osmotic potential of the soil solution when the available moisture in the soil is lower than $50 \%$. Waters based on this parameter can be classified in three classes: good (<3mmolc L-1), moderate (3-15 
mmolc $\mathrm{L}^{-1}$ ) and not recommended (>15mmolc $\mathrm{L}^{-1}$ ) (Delgado et al. 2010). Potential salinity values was calculated by using Equation (6).

$$
\text { P.S. }=\mathrm{Cl}^{-}+1 / 2 \mathrm{SO}_{4}^{2-}
$$

Soil permeability is affected by long term use of water rich in $\mathrm{Na}, \mathrm{Ca}, \mathrm{Mg}$, and $\mathrm{HCO}_{3}$. The waters with permeability index (PI) of over 75 is classified as class- 1 and assessed as the most suitable for irrigation; the water with PI values of between 25-75 are classified as class- 2 and assessed as moderately suitable for irrigation and the waters with PI value below 25 are assessed as unsuitable for irrigation (Doneen, 1964). PI values were calculated by using Equation (7).

$$
\mathrm{PI}=\left[\frac{\mathrm{Na}+\sqrt{\mathrm{HCO}_{3}}}{\mathrm{Ca}+\mathrm{Mg}+\mathrm{Na}}\right] \times 100
$$

The water used in drip irrigation should not clog the drippers. Langelier saturation index (LSI) is used to provide a basis for the clogging risk of in emitters. If the actual $\mathrm{pH}$ exceeds $\mathrm{pHs}$, the LSI is positive and being supersaturated with $\mathrm{CaCO}_{3}$. In this case, the water has a tendency to form scale (Langelier, 1936) and able to clog the drippers. Langelier saturation index (LSI) was calculated by using Equation (8).

$$
\mathrm{LSI}=\mathrm{pH}-\mathrm{pH}_{\mathrm{s}}
$$

$\mathrm{pH}=$ actual $\mathrm{pH}$ of the water, and

$\mathrm{pHs}=\mathrm{pH}$ at which water having the same alkalinity and calcium content is just saturated with calcium carbonate

\section{Results and discussion}

\subsection{Chemical and physical parameters}

Basic descriptive statistics and seasonal variations for water quality parameters of drainage canals between the periods of July 2012-January 2013 are provided in Table 5 . The pH values of July varied between 7.24-9.05 with an average value of 8.09. For irrigation waters, $\mathrm{pH}$ values are recommended to be between 6.5-8.5 (Ayers and Westcot, 1985). The values of Anbar Köprü, Karagöl, İnesli and Esenli canals were over 8.5, thus found unsuitable for irrigation. Especially in pressurized irrigation systems, the waters with a pH value over 7.0 may result in clogging and the waters with a $\mathrm{pH}$ value over 8 may result in severe clogging in irrigation systems. The $\mathrm{pH}$ values of January 2013 varied between 7.08-7.92 with an average value of 7.51. Canal waters were not found to be problematical for irrigation with regard to $\mathrm{pH}$ values.

High levels of soluble salts in soils may result in reduced plant productivity of crops and native vegetation (Rasouli et al., 2012). The EC values of July 2012 varied between $0.45-4.23 \mathrm{dS} \mathrm{m}^{-1}$ with an average value of $1.29 \mathrm{dS} \mathrm{m}^{-1}$. Since EC values of Bakir, Kocairmak, Ulaş, Arapli, Turgutlu, Anbar Köprü, Karagöl, Çobanli, Manalı, Ömerli, Esenli, Acıklı, Balkanlı and İnesli canals were over $0.75 \mathrm{dS}^{-1}$, these waters were considered as unsuitable for irrigation. The EC values of January 2013 varied between $0.16-1.44 \mathrm{dS} \mathrm{m}^{-1}$ with an average value of $0.60 \mathrm{dS} \mathrm{m}^{-1}$.

Nitrate $\left(\mathrm{NO}_{3}\right)$ concentrations over $5 \mathrm{mg} \mathrm{l}^{-1}$ in surface waters are considered as an indicator of water pollution. High nitrate concentrations over agricultural fields may either be resulted from organic matter wastes or mostly from unconscious nitrogenous (N) fertilizer treatments (Ramesh and Elango, 2012). The nitrate values of July 2012 varied between $0-14.23 \mathrm{mg} \mathrm{l}^{-1}$ with an average value of $6.64 \mathrm{mg} \mathrm{l}^{-1}$. The nitrate concentrations of Kirazlik, Hidirellez, Bakir, Kocairmak, Ulaş, Turgutlu, Anbar Köprü, Ömerli, Esenli, Acikli, Karaboğaz, Balkanli, İnesli, Şivganli and Tafli canals were above the threshold values. The nitrate concentration of January 2013 varied between $6.78-25.73 \mathrm{mg} \mathrm{l}^{-1}$ with an average value of $15.01 \mathrm{mg} \mathrm{l}^{-1}$. Thus, nitrate pollution was observed in all canals in this period. The main reason of high nitrate 
concentrations in all waters is the over-application of fertilizer on surrounding agricultural land (Al-hadithi, 2012). Nitrogen leaching through soil profile during winter precipitation increased nitrate concentrations in drainage canals.

Table 5. Descriptive statistics and significance of seasonal variations between July 2012- January 2013

\begin{tabular}{|c|c|c|c|c|c|c|c|c|c|c|c|}
\hline \multirow{2}{*}{ Parameters } & \multicolumn{4}{|c|}{ July 2012} & \multicolumn{4}{|c|}{ January 2013} & \multicolumn{3}{|c|}{ Test statistics } \\
\hline & Min. & Max. & Mean & S.D. & Min. & Max. & Mean & S.D. & $t$ test & $P$ value & Remark \\
\hline $\mathrm{pH}$ & 7.24 & 9.05 & 8.09 & 0.49 & 7.08 & 7.92 & 7.51 & 0.18 & 5.049 & 0.000 & Significant \\
\hline $\mathrm{EC}\left(\mathrm{dS} \mathrm{m}^{-1}\right)$ & 0.45 & 4.23 & 1.29 & 1.03 & 0.16 & 1.44 & 0.60 & 0.36 & 2.887 & 0.006 & Significant \\
\hline $\mathrm{Na}\left(\mathrm{mg} \mathrm{l}^{-1}\right)$ & 18.10 & 700.23 & 149.99 & 188.37 & 5.66 & 168.76 & 34.16 & 40.30 & 2.755 & 0.009 & Significant \\
\hline $\mathrm{K}\left(\mathrm{mg} \mathrm{l}^{-1}\right)$ & 3.07 & 30.22 & 9.24 & 8.24 & 1.24 & 9.27 & 3.51 & 1.90 & 3.105 & 0.003 & Significant \\
\hline $\mathrm{Ca}\left(\mathrm{mg} \mathrm{l}^{-1}\right)$ & 26.51 & 99.07 & 58.04 & 18.81 & 4.91 & 87.81 & 47.33 & 26.41 & 1.513 & 0.138 & Not significant \\
\hline$M g\left(\mathrm{mg} \mathrm{l}^{-1}\right)$ & 14.03 & 113.38 & 43.89 & 26.14 & 3.80 & 92.44 & 31.30 & 22.48 & 1.674 & 0.102 & Not significant \\
\hline $\mathrm{CO}_{3}\left(\mathrm{mg} \mathrm{l}^{-1}\right)$ & 0.00 & 21.00 & 4.29 & 7.14 & 0.00 & 0.00 & 0.00 & 0.00 & 2.751 & 0.009 & Significant \\
\hline $\mathrm{HCO}_{3}\left(\mathrm{mg} \mathrm{l}^{-1}\right)$ & 192.49 & 1873.81 & 489.89 & 440.32 & 54.29 & 483.73 & 253.88 & 142.31 & 2.337 & 0.025 & Significant \\
\hline $\mathrm{Cl}\left(\mathrm{mg} \mathrm{l}^{-1}\right)$ & 15.37 & 490.48 & 146.24 & 141.36 & 9.35 & 263.67 & 46.57 & 60.45 & 2.971 & 0.005 & Significant \\
\hline $\mathrm{SO}_{4}\left(\mathrm{mg} \mathrm{l}^{-1}\right)$ & 7.37 & 160.70 & 42.07 & 37.45 & 13.84 & 43.93 & 26.89 & 10.68 & 1.787 & 0.082 & Not significant \\
\hline $\mathrm{NO}_{3}\left(\mathrm{mg} \mathrm{l}^{-1}\right)$ & 0.00 & 14.23 & 6.64 & 3.34 & 6.78 & 25.73 & 15.01 & 7.82 & -4.512 & 0.000 & Significant \\
\hline$B\left(\mathrm{mg} \mathrm{l}^{-1}\right)$ & 0.00 & 0.37 & 0.13 & 0.11 & 0.00 & 0.00 & 0.00 & 0.00 & 5.430 & 0.000 & Significant \\
\hline
\end{tabular}

Boron is an important plant nutrient, but boron concentration over $1.0 \mathrm{mg} \mathrm{l}^{-1}$ in irrigation water may result in significant damages in most plants. While boron concentrations of July 2012 varied between $0-0.37 \mathrm{mg} \mathrm{l}^{-1}$, boron was not observed in canals in January 2013. It was observed that drainage waters did not have any problems with regard to boron concentrations in both the two periods. The boron content changed between the two periods of study.

Minareci et al. 2009 investigated the effect of seasonal change on water quality of a stream. They determined that the concentration of Boron was lower in the rainy season than dry period. They attributed the increase in the stream water boron values during summer to irrigation water boron content. Arslan and Ayyıldız Turan (2015) carried out a study in Çarşamba Plain with groundwater samples taken from 78 groundwater wells in July 2012 and investigated the water heavy metal parameters to assess the suitability of waters for drinking and irrigation. The researchers reported that the boron ranged from 0.01 to $0.97 \mathrm{mg} \mathrm{l}^{-1}$ in this period. It may be considered that the drainage water boron content was as result of groundwater that was used for irrigation purpose.

Sodium and potasium ions ranged between 18.10 and $700.23 \mathrm{mg} \mathrm{l}^{-1}, 3.07$ and $30.22 \mathrm{mg} \mathrm{l}^{-1}$ with a mean value of $149.99 \mathrm{mg} \mathrm{l}^{-1}$ and 9.24, respectively in July 2012 (Table 5). The concentrations of $\mathrm{Cl}_{\text {and }} \mathrm{SO}_{4}$ ranged from 15.37 to 490.48 , from 7.37 to $160.70 \mathrm{mg} \mathrm{l}^{-1}$ respectively with a mean value of 146.24 and 42.07 $\mathrm{mg} \mathrm{l}^{-1}$ respectively (Table 5).

The calcium concentration ranges from 26.51 to $99.07 \mathrm{mg} \mathrm{l}^{-1}$ in the July 2012 and from 4.91 to 87.81 $\mathrm{mg} \mathrm{l}^{-1}$ in January 2013. The mean concentration of magnesium in the water during the July 2012 is 43.89 $\mathrm{mg} \mathrm{l}^{-1}$, which decreases slightly to $31.30 \mathrm{mg} \mathrm{l}^{-1}$ during the January 2013. The concentration of $\mathrm{HCO}_{3}$ shows a large variation from 192.49 to $1873.81 \mathrm{mg} \mathrm{l}^{-1}$, averaging $489.89 \mathrm{mg} \mathrm{l}^{-1}$ in July 2012 and from 54.29 to $483.73 \mathrm{mg} \mathrm{l}^{-1}$, averaging $253.88 \mathrm{mg} \mathrm{l}^{-1}$ in January 2013.

As a result of the paired sample $t$ test showed that seasonal changes of $\mathrm{pH}, \mathrm{EC}, \mathrm{Na}, \mathrm{K}, \mathrm{CO}_{3}, \mathrm{HCO}_{3}, \mathrm{Cl}, \mathrm{NO}_{3}$ and boron were statistically significant (Table 5). The $t$ test showed that seasonal changes of calcium, magnesium and sulfate were statistically insignificant. Since the $p$ value was greater than the value $(p=0.138)$, and it was concluded that there is no significant difference between calcium from July to January with a $95 \%$ confidence. Based on the test, the $p$ value for $\mathrm{Mg}$ and $\mathrm{SO}_{4}$ is 0.102 and 0.082 ; this is significantly greater than $\alpha=0.05$, which indicates that there is no difference between July 2012 and January 2013 for $\mathrm{Mg}$ and $\mathrm{SO}_{4}$ in the study. All the parameters, except $\mathrm{NO}_{3}$ was found to be higher during 
summer as compared to winter period. Such an increase in nitrate concentrations mainly resulted from nitrogen leaching thorough soil profile with winter precipitations

\subsection{Hydrogeochemical classification of drainage water}

Piper diagram was prepared to visualize the chemistry of canal waters and to determine water types accordingly. In July 2012, $24 \%$ of waters were $\mathrm{Na}-\mathrm{Cl}, 5 \%$ were $\mathrm{Ca}-\mathrm{Na}-\mathrm{HCO} 3$ and the remaining $71 \%$ were $\mathrm{Ca}-\mathrm{Mg}-\mathrm{HCO}_{3}$ waters (Figure 2a). $\mathrm{Ca}-\mathrm{Mg}-\mathrm{HCO}_{3}$ waters type were found to be more during irrigation season compared to other water types. In January 2013, only one canal had $\mathrm{Na}-\mathrm{Cl}$ water type and the rest were Ca-Mg-HCO3 waters (Figure 2b). The water types changed from July 2012 to January 2013 in some of the drainage canals. The total of $797 \mathrm{~mm}$ of precipitation was received between the two season, this may have caused the variation in water types.
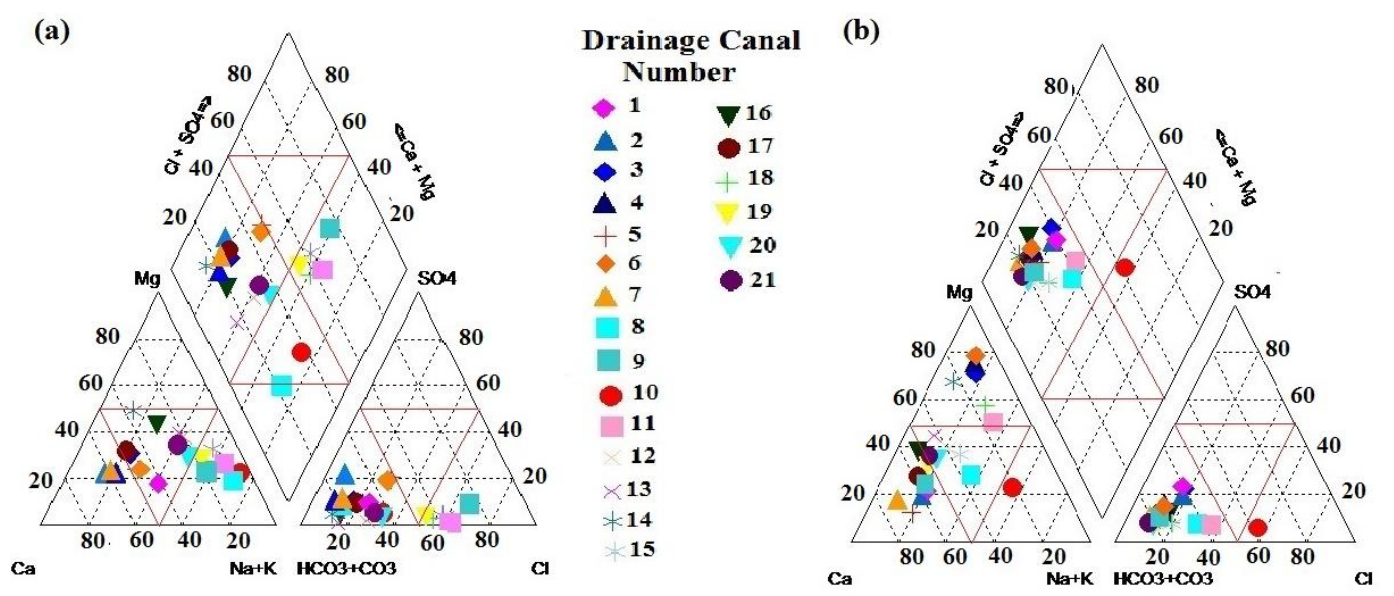

Figure 2. Piper diagram showing hydrochemical characteristics of drainage canal water in July 2012 (a) and January 2013

\subsection{Suitability for irrigation}

The results on index values calculated to assess the suitability of waters for irrigation are provided in Tables 6 and 7. The SAR values over 18 may create problems in soil structure and plant development (Richard, 1954). SAR values were below 18 in both periods. Therefore, drainage waters were found to be suitable for irrigation with regard to SAR values. It was determined that SAR values is higher, in July 2012 than in January. Al-Taani (2013) stated that the SAR values of river water in Jordan is higher during summer than winter season.

Na \% values up to 60 indicate the suitability of water for irrigation (Wilcox , 1955). In July 2012, Na\% values of Araplı, Anbar Köprü and Karagöl canals were over 60 (Table 6), thus these waters were considered as unfavorable for irrigation. In January 2013, waters of all canals were suitable for irrigation with regard to $\%$ Na values (Table 7).

According to Kumar et al. (2009), the increase of RSC in irrigation water is significantly harmful for plants growth. In July 2012, RSC value of Çobanlı canal was 1.73 and thus drainage water was considered as suspicious for irrigation. RSC values of Araplı, Anbar Köprü and Manalı canals were above 2.50, thus these wasters were assessed as unsuitable for irrigation. The waters of other canals had RSC values showing suitability for irrigation.

The Kelly's ratio of equal to or less than 1 is indicative of good quality water for irrigation whereas above 1 is suggestive of unsuitability for agricultural purpose due to alkali hazards (Karanth, 1987). The KI values of Araplı, Turgutlu, Anbar Köprü, Karagöl, Esenli, Balkanlı and İnesli canals were over 1 in July 2012 and considered as unsuitable for irrigation. In January 2013, only Anbar Köprü canal water is unsuitable for irrigation. 
Table 6. Water quality parameters of drainage canals in July 2012

\begin{tabular}{lcccccccccc}
\hline Sample No & $\begin{array}{c}\text { Name of } \\
\text { Drainage Canal }\end{array}$ & EC dS $\mathbf{~ m}^{-1}$ & SAR & \% Na & RSC & KI & MR & PI & PS & LSI \\
\hline $\mathbf{1}$ & Kirazlık & 1.186 & 2.27 & 35.91 & 0.87 & 0.61 & 30.44 & 53.69 & 3.40 & 0.37 \\
$\mathbf{2}$ & Hıdırellez & 0.52 & 0.51 & 13.89 & -0.79 & 0.17 & 26.99 & 32.16 & 1.05 & 0.44 \\
$\mathbf{3}$ & Bakır & 0.752 & 0.86 & 20.14 & -0.47 & 0.26 & 40.07 & 39.81 & 1.54 & 0.44 \\
$\mathbf{4}$ & Sel Yeri & 0.545 & 0.71 & 18.35 & 0.06 & 0.23 & 28.68 & 38.37 & 0.84 & 0.33 \\
$\mathbf{5}$ & Kocaırmak & 0.832 & 1.39 & 28.00 & -1.71 & 0.40 & 33.96 & 44.11 & 3.31 & 0.83 \\
$\mathbf{6}$ & Ulaş & 0.786 & 1.42 & 28.84 & -1.38 & 0.41 & 34.55 & 45.58 & 3.08 & 0.58 \\
$\mathbf{7}$ & Abdal & 0.449 & 0.56 & 16.33 & -0.27 & 0.20 & 29.06 & 37.01 & 0.85 & 0.44 \\
$\mathbf{8}$ & Araplı & 4.09 & 11.99 & 70.73 & 19.95 & 2.56 & 68.08 & 85.28 & 7.06 & 2.15 \\
$\mathbf{9}$ & Turgutlu & 1.246 & 4.59 & 57.13 & -2.28 & 1.39 & 55.47 & 72.27 & 9.45 & 0.87 \\
$\mathbf{1 0}$ & Anbar Köprü & 4.23 & 12.86 & 71.85 & 15.07 & 2.72 & 83.20 & 86.86 & 14.84 & 2.67 \\
$\mathbf{1 1}$ & Karagöl & 2.09 & 6.96 & 63.04 & -0.15 & 1.79 & 73.78 & 79.13 & 13.73 & 1.76 \\
$\mathbf{1 2}$ & Çobanlı & 1.24 & 2.74 & 40.40 & 1.73 & 0.69 & 65.11 & 61.42 & 3.79 & 1.26 \\
$\mathbf{1 3}$ & Manalı & 1.45 & 2.71 & 37.28 & 3.74 & 0.61 & 65.12 & 58.46 & 2.55 & 1.37 \\
$\mathbf{1 4}$ & Ömerli & 0.938 & 0.63 & 13.47 & -0.18 & 0.16 & 57.85 & 33.00 & 1.23 & 1.14 \\
$\mathbf{1 5}$ & Esenli & 1.257 & 3.99 & 54.78 & -1.18 & 1.24 & 74.86 & 73.45 & 7.03 & 1.79 \\
$\mathbf{1 6}$ & Acıklı & 0.796 & 1.26 & 25.93 & 0.67 & 0.36 & 60.02 & 48.85 & 1.41 & 1.31 \\
$\mathbf{1 7}$ & Taflı & 0.727 & 2.07 & 40.44 & 0.53 & 0.69 & 58.62 & 62.92 & 2.39 & 0.91 \\
$\mathbf{1 8}$ & Şıvganlı & 1.015 & 3.10 & 47.29 & 1.23 & 0.91 & 56.51 & 66.82 & 3.82 & 1.32 \\
$\mathbf{1 9}$ & Inesli & 0.849 & 3.31 & 52.83 & -0.39 & 1.15 & 61.42 & 71.71 & 4.76 & 1.46 \\
$\mathbf{2 0}$ & Balkanlı & 1.32 & 5.00 & 59.57 & 0.20 & 1.50 & 69.41 & 76.96 & 7.84 & 1.21 \\
$\mathbf{2 1}$ & Karaboğaz & 0.699 & 0.81 & 19.13 & -0.61 & 0.24 & 40.21 & 38.17 & 1.71 & 0.51 \\
\hline
\end{tabular}

Magnesium ratio (MR) is another parameter used to assess the suitability of waters for irrigation. Increasing values reduce the suitability of waters for irrigation. MR values should be below $50 \%$ to be considered for irrigation (Szabolcs and Darab, 1964). In July 2012, MR values varied between $27-83 \%$. Based on these values, drainage waters in Araplı, Anbar Köprü, Karagöl, Çobanlı, Manalı, Ömerli, Esenli, Acıklı, Balkanlı, İnesli, Şıvganlı and Taflı canals may create problems in irrigation. In January 2013, MR values varied between $15-91 \%$ and waters of Bakır, Selyeri Ulaş, Anbarköprü, Karagöl, Çobanlı, Manalı, Ömerli, Esenli and Balkanlı canals were found to be unsuitable for irrigation. On the other hand, Kirazlık, Hıdırellez, Kocaırmak, Abdal, Araplı, Turgutlu, Acıkl, Karaboğaz, İnesli, Şıvganlı and Taflı canals do not create any problems in irrigation with regard to MR values.

PI values varied between 32.16 - 86.86 in July 2012. Based on these values, waters of Araplı, Anbar Köprü, Karagöl and Balkanlı canals were classified as first class, which means it is most suitable for irrigation and the rest was classified as second class, that is moderately suitable for irrigation (Doneen, 1964). In January 2013 , PI values varied between $25.63-70.83$ with an average value of 41.78 and all waters were classified as second class.

PS values of drainage canals varied between 0.84 - 14.84 with an average value of 4.56 in July 2012. Based on these values, Kirazlık, Kocaırmak, Ulaş, Araplı, Turgutlu, Anbar Köprü, Karagöl, Çobanlı, Esenli, Balkanlı, Inesli and Şıvanlı canals were classified as moderate and the rest was classified as good for irrigation (Delgado et al. 2010). In January 2013, PS values varied between 0.41 -7.79 with an average value of 1.59. Considering these values, Araplı, Anbar Köprü and Karagöl canals were moderate and the rest were good for irrigation.

LSI values varied between $0.33-2.67$ in July 2012 (Table 6) and all canals were assessed as unsuitable to be used in drip irrigation (Langelier, 1936). The waters with positive LSI values may result in clogging in drippers. In January 2013, LSI values varied between -0.41 and 2.19 of which 5 canals had negative values and 16 canals had positive values (Table 7). 
Table 7. Water quality parameters of drainage canals in January 2013

\begin{tabular}{cccccccccc}
\hline Sample No & EC dS/m & SAR & \%Na & RSC & KI & MR & PI & PS & LSI \\
\hline $\mathbf{1}$ & 0.416 & 0.64 & 19.57 & -0.87 & 0.25 & 27.69 & 39.61 & 1.1 & -0.41 \\
$\mathbf{2}$ & 0.159 & 0.31 & 15.69 & -0.33 & 0.2 & 24.91 & 45.86 & 0.41 & -0.66 \\
$\mathbf{3}$ & 0.163 & 0.33 & 15.21 & -0.76 & 0.18 & 85.44 & 49.3 & 0.43 & -0.74 \\
$\mathbf{4}$ & 0.236 & 0.33 & 12.45 & -1.05 & 0.14 & 88.14 & 42.84 & 0.46 & -0.37 \\
$\mathbf{5}$ & 0.339 & 0.5 & 18.01 & -0.15 & 0.22 & 15.18 & 40.94 & 0.69 & 0.22 \\
$\mathbf{6}$ & 0.305 & 0.36 & 11.8 & -1.47 & 0.14 & 90.6 & 39.1 & 0.6 & 0.1 \\
$\mathbf{7}$ & 0.34 & 0.27 & 9.63 & -0.36 & 0.11 & 19.98 & 31.45 & 0.49 & 0.22 \\
$\mathbf{8}$ & 1.203 & 2.24 & 35.98 & -0.35 & 0.57 & 44.03 & 53.09 & 4.08 & 1.48 \\
$\mathbf{9}$ & 0.615 & 0.73 & 18.36 & -0.36 & 0.23 & 30.02 & 36.94 & 1.18 & 1.08 \\
$\mathbf{1 0}$ & 1.439 & 4.3 & 54.81 & -0.9 & 1.26 & 51.84 & 70.83 & 7.79 & 1.76 \\
$\mathbf{1 1}$ & 1.038 & 1.93 & 32.85 & -1.83 & 0.5 & 76.92 & 54.77 & 3.96 & 1.7 \\
$\mathbf{1 2}$ & 0.928 & 1.08 & 20.92 & -0.18 & 0.27 & 50.06 & 39.55 & 1.74 & 1.25 \\
$\mathbf{1 3}$ & 0.91 & 0.59 & 12.21 & -0.95 & 0.14 & 51.49 & 29.43 & 1.56 & 1.12 \\
$\mathbf{1 4}$ & 0.878 & 0.42 & 8.45 & -2.62 & 0.09 & 74.76 & 25.94 & 1.56 & 1.21 \\
$\mathbf{1 5}$ & 0.919 & 1.38 & 26.62 & -0.21 & 0.37 & 50.93 & 45.98 & 2.23 & 2.19 \\
$\mathbf{1 6}$ & 0.595 & 0.3 & 8.09 & -1.47 & 0.09 & 42.27 & 25.63 & 1.37 & 1.06 \\
$\mathbf{1 7}$ & 0.574 & 0.54 & 14.09 & -0.23 & 0.17 & 42.71 & 34.76 & 0.84 & 0.97 \\
$\mathbf{1 8}$ & 0.493 & 0.62 & 17.45 & -0.09 & 0.22 & 43.3 & 40.03 & 0.8 & 1.03 \\
$\mathbf{1 9}$ & 0.423 & 0.49 & 14.97 & -0.32 & 0.18 & 38.64 & 37.59 & 0.77 & 1.41 \\
$\mathbf{2 0}$ & 0.392 & 0.92 & 25.88 & -0.53 & 0.36 & 79.95 & 55.05 & 0.9 & 0.77 \\
$\mathbf{2 1}$ & 0.251 & 0.31 & 12.61 & -0.34 & 0.15 & 32.16 & 38.66 & 0.49 & -0.21 \\
\hline
\end{tabular}

To assess the suitability of waters for irrigation, USSL salinity diagram was also prepared in this study by using electrical conductivity (EC) and sodium adsorption ratio (SAR) of the waters (Figures 3a, 3b) (USSL, 1954).
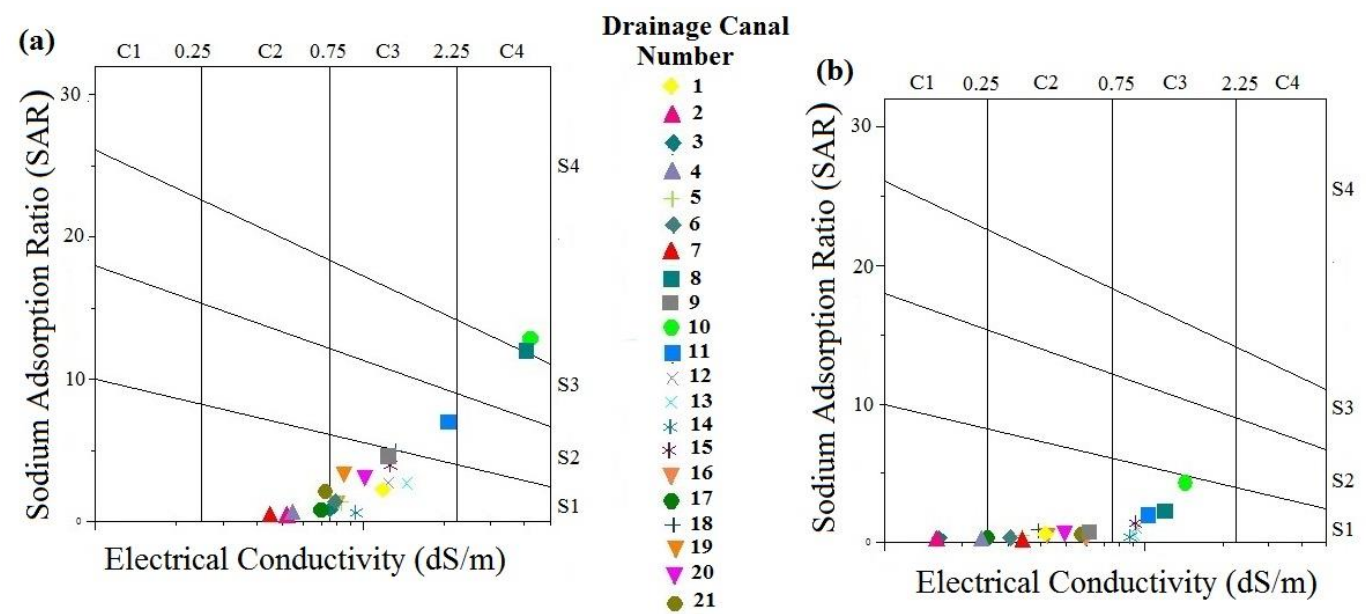

Figure 3. Classification of irrigation water quality, with respect to salinity hazard and sodium hazard (after USSL 1954)

Table 8 shows the distribution of classes of salinity and sodicity of water. In July 2012, waters were mostly placed in $\mathrm{C}_{3} \mathrm{~S}_{2}$ class indicating high salinity and moderate sodicity risk. One canal had $\mathrm{C}_{3} \mathrm{~S}_{2}$ and 2 canals had $\mathrm{C}_{4} \mathrm{~S}_{4}$ class waters and considered as unsuitable for irrigation under normal conditions. In January 2013, waters mostly classified in $\mathrm{C}_{2} \mathrm{~S}_{1}$ class and can be used in irrigation of several plants without any problems. An improvement was observed in water quality parameters in winter season because of precipitations. 
However, $34 \%$ of waters were still in $\mathrm{C}_{3} \mathrm{~S}_{1}$-class just because of leaching of salts accumulated in irrigation seasons with winter precipitations.

Table 8. Repartition of classes of salinity and sodicity of irrigation water

\begin{tabular}{cccccc}
\hline \multirow{2}{*}{ Class of salinity (C) and sodicity $(\mathbf{S})$} & \multicolumn{2}{c}{ July $\mathbf{2 0 1 2}$} & \multicolumn{2}{c}{ January 2013} \\
\cline { 2 - 6 } & Number of wells & Percent of wells & Number of wells & Percent of wells \\
\hline$C_{1} S_{1}$ & - & - & 3 & 14 \\
\hline$C_{2} S_{1}$ & 5 & 24 & 11 & 52 \\
\hline$C_{3} S_{1}$ & 14 & 62 & 7 & 34 \\
\hline$C_{3} S_{2}$ & 1 & 5 & - & - \\
\hline$C_{4} S_{4}$ & 2 & 9 & - & - \\
\hline
\end{tabular}

\section{Conclusions}

Water quality of 21 drainage canals and variations in water quality parameters between two periods were investigated in this study. Suitability of drainage waters for irrigation was also assessed through SAR, \%Na, RSC, KI, MR, LSI, PI and PS-like indexes.

Piper diagram was used to visualize water chemistry and to perform water classification. In July 2012, waters were classified as $\mathrm{Ca}-\mathrm{Mg}-\mathrm{HCO}, \mathrm{Na}-\mathrm{Cl}$ and $\mathrm{Ca}-\mathrm{Na}-\mathrm{HCO} 3$ waters. In January 2013, except for one canal, drainage waters were all $\mathrm{Ca}-\mathrm{Mg}-\mathrm{HCO} 3$ waters.

Except for $\mathrm{Ca}, \mathrm{Mg}$ and $\mathrm{SO}_{4}$, water quality parameters exhibited significant temporal variations. Only the $\mathrm{NO}_{3}$ concentrations increased whereas other parameters decreased.

According to USSL diagram, drainage waters were mostly classified in $C_{2} S_{1}$ or $C_{3} S_{1}$ and 2 canals were classified in $\mathrm{C}_{4} \mathrm{~S}_{4}$ in July 2012 and some of them should not be used in irrigations. In January 2013, waters were classified in $\mathrm{C}_{1} \mathrm{~S}_{1}, \mathrm{C}_{2} \mathrm{~S}_{1}$ and $\mathrm{C}_{3} \mathrm{~S}_{1}$-classes. The Arapl, Ambar Köprü and Karagöl canals with high salinity levels before the irrigation season also had high salinity levels after the irrigation season. Such a case indicated high soil salinity levels of the region.

In assessments made to determine the suitability of drainage waters for irrigations, it was observed that $14 \%$ of samples had \% Na and RCS problems, 33\% had KI and 62\% had MR problems in July 2012 and these waters were considered as unsuitable for irrigations. Also entire waters were considered as unsuitable for drip irrigation with regard to LSI values.

Various problems have been experienced over the fields irrigated with drainage waters. Salinity is the leading one of these problems. Therefore, drainage waters should be avoided in irrigations for better land and water management. However, in regions without any water resources other than drainage waters, suitability of water for irrigations should be assessed through different methods before the irrigation season.

\section{Acknowledgments}

This study was supported by Ondokuz Mayıs University, Scientific Research Programs under the project no. PYO.ZRT.1904.12.020.

\section{References}

Alexakis D., Gotsis D. and Giakoumakis S. (2012), Assessment of drainage water quality in pre and post-irrigation seasons for supplemental irrigation use, Environ Monit. Assess, 184, 5051-5063.

Al-Taani AA. (2013), Seasonal variations in water quality of Al-Wehda Dam north of Jordan and water suitability for irrigation in summer, Arab J Geosci., 6(4), 1131-41140.

Arslan H. and Demir Y. (2013), Impacts of Seawater Intrusion on Soil Salinity and Alkalinity in Bafra Plain, Turkey, Environmental Monitoring and Assessment, 185(2), 1027-1040. 
Arslan H. and Ayyildiz Turan N. (2015), Estimation of spatial distribution of heavy metals in groundwater using interpolation methods and multivariate statistical techniques; its suitability for drinking and irrigation purposes in the Middle Black Sea Region of Turkey, Environmental Monitoring and Assessment, 187, 516. doi: 10.1007/s10661-015-4725-x

Arumugam K. and Elangovan. K. (2009), Hydrochemical characteristics and groundwater quality assessment in Tirupur Region, Coimbatore District, Tamil Nadu, India, Environ Geol., 58,1509-1520.

Ayers RS. and Westcot DW. (1985), Water quality for agriculture. Irrigation and drainage paper 29 (rev.1). FAO, Rome

Dhembare A.J. (2012), Assessment of Water Quality Indices for Irrigation of Dynaneshwar Dam Water, Ahmednagar, Maharashtra, India, Archives of Applied Science Research, 4(1), 348-352.

Eaton F.M. (1950), Significance of carbonates in irrigated waters, Soil Science, 69, 127-128. doi:10.1097/00010694195002000-00004.

Doneen L.D. (1964), Water quality for Agriculture. Department of Irrigation, University of California, Davis, USA, pp 48.

Delgado C., Pacheco J., Cabrea A., Baltlori E., Orellana R. and Baustista F. (2010), Quality of groundwater for irrigation in tropical karst environment; the case of Yucatan, Mexico, Agricultural Water Management, 97, 1423-1433.

Ishaku J.M., Ahmed A.S. and Abubakar M.A. (2012), Assessment of groundwater quality using chemical indices and GIS mapping in Jada area, Northeastern Nigeria, International Research Journal of Geology and Mining, 2(3), 54-61.

Karanth K. R. (1987), Groundwater assessment, development and management, Tata-McGraw Hill Publishing Company Limited, New Delhi

Kelly W.P. (1940), Permissible composition and concentration of irrigated waters. In: Proceedings of the A.S.C.F 607.

Kontis E.E. and Gaganis P. (2012), Hydrochemical characteristics and groundwater quality in the Island of Lesvos, Greece, Global Nest Journal, 14 (1), 422-430.

Kumar S. K., Rammohan V., Sahayam, J. And Jeevanandam, M. (2009), Assessment of groundwater quality and hydrogeochemistry of Manimuktha River basin, Tamil Nadu, India. Environmental Monitoring and Assessment 159, 341-351.

Langlier W.F. (1936), The analytical control of anti-corrosion water treatment. J Am Water Work Assoc., 28, 15001521.

Minareci O., Minareci E. and Öztürk M. (2009), Investigation of Detergent, Phosphate and Boron Pollution in Karaçay (Manisa), Journal of Fisheries \& Aquatic Sciences, 26(3), 171-177

Nag S.K. and Ghosh P. (2013), Variation in Groundwater Levels and Water Quality in Chhatna Block, Bankura District, West Bengal - A GIS Approach, Journal Geological Society of India, 81, 261-280

Rama B., Manoj K. and Kumar P.P. (2013), Index Analysis, Graphical and Multivariate Statistical Approaches for Hydrochemical Characterisation of Damodar River and its Canal System, Durgapur, West Bengal, India, International Research Journal of Environment Sciences, 2(2), 53-62

Ramesh K. and Elango L. (2012), Groundwater quality and its suitability for domestic and agricultural use in Tondiar river basin, Tamil Nadu, India, Environmental Monitoring Assessment, 184, 3887-3899.

Rasouli F., Pouya A.K. and Cheraghi S.A.M. (2012). Hydrogeochemistry and water quality assessment of the KorSivand Basin, Fars province, Iran, Environ Monit Assess., 184, 4861-4877.

Richard L.A. (1954), Diagnosis and improvement of saline and alkaline soils. In: Agricultural hand book, vol 60. USDA, Washington, DC, p 160.

Sadashivaiah C., Ramakrishnaiah C.R. and Ranganna G. (2008), Hydrochemical Analysis and Evaluation of Groundwater Quality in Tumkur Taluk, Karnataka State, India, International Journal of Environmental Research and Public Health, 5(3),158-164.

Seth R., Mohan M., Singh P., Singh R., Dobhal R., Singh KP. and Gupta S. (2014), Water quality evaluation of Himalayan Rivers of Kumaun region, Uttarakhand, India, App/ Water Sci., doi:10.1007/s13201-014-0213-7

Singh A.K., Raj B., Tiwari A.K. and Mahato M.K. (2013), Evaluation of hydrogeochemical processes and groundwater quality in the Jhansi district of Bundelkhand region, India, Environ Earth Sci., 70, 1225-1247. 
Szabolcs I. and Darab C. (1964), The influence of irrigation water of high sodium carbonate content on soils. In I. Szabolics (Ed.), Proc 8th International Congress Soil Science Sodics Soils, Res Inst Soil Sci Agric Chem Hungarian Acad Sci, ISSS Trans II, 1964, 802-812.

Thivya C., Chidambaram S., Singaraja C., Thilagavathi R., Prasanna M.V., Anandhan P. and Jainab I. (2013), A study on the significance of lithology in groundwater quality of Madurai district, Tamil Nadu (India), Environ Dev Sustain., 15(5), 1365-1387.

US Salinity Laboratory Staff (1954), Diagnosis and improvement of saline and alkali soils. US Department of Agriculture, Handbook No. 60, pp: 160.

Vetrimurugan E. and Elango L. (2015), Groundwater Chemistry and Quality in an Intensively Cultivated River Delta, Water Qual Expo Health, 7, 125-141.

Wanda E., Gulula L.C. and Phiri A. (2013), Hydrochemical assessment of groundwater used for irrigation in Rumphi and Karonga districts, Northern Malawi, Physics and Chemistry of the Earth, 66, 51-59.

Wilcox L. V. (1955), Classification and use of irrigation waters. USDA, circular 969, Washington, DC, USA

Yidana S.M., Yakubo B.B., Aliou A.S. and T Akabzaa M. (2012), Groundwater quality in some Voltaian and Birimian aquifers in northern Ghana-application of multivariate statistical methods and geographic information systems, Hydrological Sciences Journal - Journal des Sciences Hydrologiques, 57(6), 1168-1183.

Zrelli B.T., Azaza F.H. Gueddari M. and Bouhlila R. (2012), Geochemistry and quality assessment of groundwater using graphical and multivariate statistical methods. A case study: Grombalia phreatic aquifer (Northeastern Tunisia), Arab J. Geoscience, 6, 3545-3561. 